\title{
Healthy Value and Quality Characteristics of Yoghurt as Affected by Different Concentrations of Cinnamon and Dill Ethanolic Extracts
}

\author{
El-Shreef, M. M. ${ }^{1}$; M. R. El-Said Shahein ${ }^{1}$; A. M. Abou El-Nour ${ }^{2}$ and M. M. K. Metwally ${ }^{{ }^{*}}$ \\ ${ }^{1}$ Food and Dairy Sciences and Technology Department, Faculty of Environmental Agricultural Sciences, \\ Suez Canal University, El-Arish, Egypt. \\ ${ }^{2}$ Dairy Department, Faculty of Agriculture, Suez Canal University, Ismailia, Egypt.
}

\section{Received: $19 / 10 / 2015$}

\begin{abstract}
This work was carried out to evaluate the effect of addition of ethanolic extract of cinnamon bark (Ci) and dill (D) seed on health value and quality of resultant yoghurt. These extracts were added at levels of 0.0, o.2, 0.4, 0.6, and $0.8 \mathrm{gm} / 1$ to cow's milk. Addition of these extracts significantly reduced the time of yoghurt coagulation and decreased the $\mathrm{pH}$ values significantly. Also these extracts significantly increased the antioxidant activity and Total Phenolic Content (TPC) of resultant yoghurt. Treated yoghurt also showed significant higher content of acetaldehyde and diacetyle than control yoghurt. Also treated yoghurt showed lower synersis and higher values for firmness and apparent viscosity than control. Addition of cinnamon up to $0.6 \mathrm{gm} / 1$ and dill extract at $0.4 \mathrm{gm} / 1$ showed acceptable organoleptic properties for resultant yoghurt. More over $\mathrm{Ci}$ extract was more effective than $\mathrm{D}$ extract in improving organoleptic properties.
\end{abstract}

Keywords: Yoghurt, Cinnamon, Dill ethanolic extracts, Antioxidant activity, Total Phenolic Content.

\section{INTRODUCTION}

The oxidative stability of milk and dairy products is of concern to the dairy industry. Oxidation processes in milk can result in strong off-flavors and deterioration of the nutritional quality of milk. The oxidative stability of milk and dairy products is the result of a delicate balance between the anti- and pro-oxidative processes in milk influenced by factors such as degree of fatty acid unsaturation, content of transition metal ions, and content of antioxidants as tocopherols and carotenoids.

However, factors such as processing, packaging and storage conditions also affect the shelf-life of pasteurized milk, since the two main mechanisms of milk quality deterioration are chemical oxidation through oxygen permeation and light-induced oxidation. At this moment, the oxidative stability of milk and dairy products in function of time is monitored by measuring lipid oxidation (lipid hydroperoxides, thiobarbituric acid reactive species, hexanal, volatile lipid oxidation), protein oxidation (dityrosine, carbonyl assay, free sulphydryl groups), content of vitamins (riboflavin, tocopherols, carotenoids), or the use of a sensory panel (Smet et al., 2008).

In recent years, many consumers have developed an interest in learning more about nutrition and food. Consumers want food that is inherently healthy, yet easy to prepare and consume, especially with women and men working an average of 7 and $8 \mathrm{~h}$ per day, respectively (Gonzalez et al., 2011).

Cinnamomum zeylanicum is one of the world's oldest spices that has been used as a natural preservative in food, beverage and cosmetic industries. Its oil has been reported to inhibit the growth and subsequent toxin production of Aspergillus parasitucus at 200-250 $\mu \mathrm{g} / \mathrm{mL}$. It has been reported that application of cinnamon revealed potent antimicrobial effects against Clostridium perfringens, Bacteroïdes fragilis and Bifidobacterium bifidus (Senhaji et al., 2007). Dill is an annual herb. Its leaves and seeds are used as seasoning and essential oil extracted from leaves and seeds also used in chewing gums, candies and pickles. Dill leaf consumption could lower the risk of cancer and reduce the level of cholesterolaemia. Dill leaf, seed and their essential oil could provide good antioxidant activities.

Antioxidants act as radical scavengers, inhibit lipid peroxidation and other free radical-mediated processes and are able to protect the human body as well as processed foods from oxidative damage attributed to the reaction of free radicals (Rathore et al., 2013).numerous food products require protection against microbial spoilage during their shelf life.

The growing demand of consumers for safe and natural products, without chemical preservatives, has resulted in thorough investigations from food authorities and researchers to assess the feasibility of mild preservation techniques and to improve the microbial quality and safety of products, while maintaining their good nutritional and organoleptic properties.

Essential oils (EOs) are volatile oily liquids obtained from different plant parts and widely used as food flavors. In spite of having been long recognized for their antibacterial, antifungal, antiviral, insecticidal and antioxidant properties, the recent interest in alternative natural substances has led to a new scientific awareness of these substances (Goni et al., 2009).

The objective of this study was to examine the effect of cinnamon bark and dill seed methanolic extracts on the chemical and rheological properties of yoghurt.

\section{MATERIALS AND METHODS}

\section{Materials}

Fresh cow's milk was obtained from the herd of Faculty of Agriculture, Suez Canal University, Ismailia Governorate, Egypt. And the composition of milk was standardized to $4 \%$ fat, $0.19 \%$ acidity $3 \%$ Casein, $3.55 \%$ Protein, $15.32 \%$ T.S, $11.32 \%$ S.N.F and $\mathrm{pH}$ value 6.4.Direct Vat Starter (DVS) yoghurt culture was 
obtained from CHR-Hansen's laboratorie, Denmark, under commercial name type (FD-DVS-YC-X11) containing Streptococcus thermophiles and Lactobacillus delbrueckii ssp. bulgaricus. Bark of cinnamon and seeds of dill were purchased from market of herbal medicines in El-Arish, North Sinai Egypt. Then they processed immediately and the oil was extracted.2,2-diphenyl-1-picrylhydrazyl (DPPH), Folin $\&$ Ciocalteu's phenol reagent were obtained from Egyptian international center for import, Nasr City, Cairo, Egypt.

\section{Preparation of yoghurt}

In a primary studies, the solvent extracts (SE) of cinnamon (Ci) and dill (D) were add to yoghurt milk before incubation. The resultants yoghurt were judged for organoleptic properties. The best results were as follows:

\section{Extracts concentrations of $\mathbf{C i} \& \mathrm{D}$}

\begin{tabular}{lllll}
$\mathbf{( S E )} \mathbf{g m} / \mathbf{1 L}$ of & 0.2 & 0.4 & 0.6 & 0.8 \\
Milk (mg) & & & & \\
\hline
\end{tabular}

$5 \mathrm{~kg}$ fresh cow's milk (standardized to $15.32 \%$ TS $\$ 11.32 \%$ SNF using skim milk powder) was heated at $95^{\circ} \mathrm{C}$ for $5 \mathrm{~min}$ (Vahedi et al., 2008), cooled to $42^{\circ} \mathrm{C}$ and incubated with starter culture then divided into five equal parts each of (1L) for each plant. The first part as a control (C) while $0.2,0.4,0.6$, and $0.8 \mathrm{gm}$ of solvent extract (SE) were added to the rest four parts as (Ci1), (Ci2), (Ci3) and (Ci4)and (D1), (D2), (D3) and (D4). The resultant yoghurt was stored at $4^{\circ} \mathrm{C}$ for up to 12 days and examined for $\mathrm{pH}$, fat, antioxidant activity, total phenolic content, acetaldehyde and diacetyle and TBA. At the same time some rheological properties including firmness, whey separation, apparent viscosity, plastic viscosity, and consistency index were carried out. All data are an average of three replicates.

\section{Methods of analysis \\ a. Milk}

Chemical composition of milk was determined according to AOAC. (1995).

\section{b. Yoghurt analysis}

Yoghurt samples were chemically analyzed and organoleptically when fresh and after 4, 8, and 12 days of cold storage. $\mathrm{pH}$ values were measured using Jenway $\mathrm{pH}$ meter with Jenway spear electrode No:29010 (Jenway limited Gransmore Green, Felsted, Dunmow, England). Acetaldehyde and diacetyl content of yoghurt samples were estimated according to (Lee and jago, 1969). Synersis (Whey off) was measured with centrifugation method (Abou El-Nour et al., 2004). Firmness of yoghurt was determined at $7^{\circ} \mathrm{C}$ according to (Abou El-Nour et al., 2004). Apparent viscosity was measured in yoghurt samples with a Brookfield rotational viscometer; model RV III (Brookfield Engineering laboratories Inc., MA, USA). A cylindrical spindle (Spindle No. SC4-14) was used in the determination of viscosity. All viscosity readings were taken at $5^{\circ} \mathrm{C}$ in shear rate ranging from $\left(0.8\right.$ to $\left.8.0 \mathrm{~s}^{-1}\right)$. All rheological parameters were performed in quad replicates. Flow curves for yoghurt were drawn from measured values of apparent dynamic viscosity \& shear rate, shear stresses \& shear rate, plastic viscosity \& treatments and consistency index \& treatments. The whole experiment was repeated three replicates for each sample. Extraction of antioxidative compounds in yoghurt was carried out ( $\mathrm{Li}$ et al., 2009). The antioxidant activity of prepared yoghurt samples was determined by DPPH method (Ravichandran et al., 2013).

The total phenolic content (TPC) of the previously prepared yoghurt samples were determined using the Folin-Ciocalteau method (Li et al., 2009). Thiobarbaturic acid (TBA) was estimated using method of (Pearson, 1976). Organoleptic properties of yoghurt samples were evaluated according to (Tamime and Robinson, 1999). All measurements were done in triplicate and analysis of variance with two factorial (treatments and storage period) were conducted by the procedure of General Linear Model (GLM) (Costat, 1998) under windows software version 6.311 and least significant different (LSD) test were employed to determine significant difference at $\mathrm{p}<0.05$.

\section{RESULTS AND DISCUSSION}

\section{Effect of cinnamon and dill ethanolic extract on the acid development of fermented milk}

Data presented in Table (1) shows that time needed to reach $\mathrm{pH} 4.6$ was decreased by adding these extracts to milk, and it gradually decreased with increasing the additives concentration. These results clearly indicated that yoghurt with $\mathrm{Ci}$ and $\mathrm{D}$ extracts had faster $\mathrm{pH}$ lowering rates than plain yoghurt. Reaching $\mathrm{pH} 4.6$ was faster for cinnamon extract yoghurt followed by dill extract yoghurt and plain yoghurt. The $\mathrm{pH}$ reduction rates for all yoghurt treatments were between 135 and 170 min compared to $180 \mathrm{~min}$ for control. This suggests that $\mathrm{Ci}$ and $\mathrm{D}$ extracts enhanced the metabolic activity of yoghurt bacteria (Amirdivani and Baba, 2011).

\section{Chemical properties of yoghurt \\ 2.1. $\mathrm{pH}$ values}

Based on the results presented in Tables (2 and 3) addition of cinnamon and dill extracts with different concentrations decreased the $\mathrm{pH}$ values significantly of fresh yoghurt sample. Moreover, increasing $\mathrm{Ci}$ and $\mathrm{D}$ extracts concentrations decreased the $\mathrm{pH}$ values significantly compared with control sample to be 4.54 , 4.56 and 4.68 for $\mathrm{Ci}, \mathrm{D}$ and plain yoghurt respectively. Afterwards the $\mathrm{pH}$ values were continuously decreasing significantly for all the samples during the 12 days of storage period at $4^{\circ} \mathrm{C}$ this attributed to the continuation of metabolic activity of starter culture (Foda et al., 2007). At the end of this period (12 days) the $\mathrm{pH}$ values for the $\mathrm{Ci}$ and $\mathrm{D}$ yoghurt samples was lower than plain yoghurt. Yoghurt containing $0.8 \mathrm{mg} \mathrm{Ci}$ extract showed the lowest $\mathrm{pH}$ values followed by dill and plain yoghurt to be $4.44,4.45$ and 4.57 respectively (Tseng and Zhao, 2012). 
Table (1): Time needed to reach pH 4.6 during fermentation of milk supplemented with different concentrations of cinnamon and dill extracts.

\begin{tabular}{lcc}
\hline Concentrations $(\mathrm{gm} / \mathrm{l})$ & Cinnamon & Dill \\
\hline Tim (min) to reach pH 4.6 & 180 & \\
Control & 160 & 180 \\
$\mathbf{0 . 2}$ & 150 & 170 \\
$\mathbf{0 . 4}$ & 140 & 155 \\
$\mathbf{0 . 6}$ & 135 & 145 \\
$\mathbf{0 . 8}$ & & 140 \\
\hline
\end{tabular}

Table (2): $\mathrm{pH}$ values of yoghurt supplemented with different concentrations of cinnamon extract.

\begin{tabular}{lccccccc}
\hline \multirow{2}{*}{ Storage period (Days) } & \multicolumn{5}{c}{ Treatments } & \multirow{2}{*}{ Mean } \\
\cline { 2 - 6 } Zero time & $\mathbf{C}$ & $\mathbf{C i}_{\mathbf{1}}$ & $\mathbf{C i}_{\mathbf{2}}$ & $\mathbf{C i}_{3}$ & $\mathbf{C i}_{4}$ & \\
\hline $\mathbf{4}$ & 4.68 & 4.64 & 4.61 & 4.57 & 4.54 & $4.61^{\mathrm{a}}$ \\
$\mathbf{8}$ & 4.65 & 4.61 & 4.58 & 4.55 & 4.5 & $4.57^{\mathrm{b}}$ \\
$\mathbf{1 2}$ & 4.61 & 4.56 & 4.54 & 4.5 & 4.46 & $4.53^{\mathrm{c}}$ \\
$\mathbf{M}$ & 4.57 & 4.51 & 4.49 & 4.46 & 4.44 & $4.49^{\mathrm{d}}$ \\
\cline { 2 - 6 } & $4.63^{\mathrm{a}}$ & $4.58^{\mathrm{b}}$ & $4.55^{\mathrm{c}}$ & $4.52^{\mathrm{d}}$ & $4.48^{\mathrm{e}}$ & \\
\hline
\end{tabular}

C: control- $\mathrm{Ci}_{1}: 0.2-\mathrm{Ci}_{2}: 0.4-\mathrm{Ci}_{3}: 0.6-\mathrm{Ci}_{4}: 0.8(\mathrm{gm} / \mathrm{L})$

${ }^{*}$ The different letters means significant

Table (3): $\mathrm{pH}$ values of yoghurt supplemented with different concentrations of dill extract.

\begin{tabular}{lccccccc}
\hline & \multicolumn{5}{c}{ Treatments } & & Mean \\
\cline { 2 - 7 } Storage period (Days) & $\mathbf{C}$ & $\mathbf{D}_{\mathbf{1}}$ & $\mathbf{D}_{\mathbf{2}}$ & $\mathbf{D}_{\mathbf{3}}$ & $\mathbf{D}_{\mathbf{4}}$ & \\
\hline Zero time & 4.68 & 4.66 & 4.64 & 4.6 & 4.56 & $4.63^{\mathrm{a}}$ \\
$\mathbf{4}$ & 4.65 & 4.62 & 4.6 & 4.57 & 4.53 & $4.59^{\mathrm{b}}$ \\
$\mathbf{8}$ & 4.61 & 4.58 & 4.56 & 4.53 & 4.48 & $4.55^{\mathrm{c}}$ \\
$\mathbf{1 2}$ & 4.57 & 4.54 & 4.5 & 4.48 & 4.45 & $4.51^{\mathrm{d}}$ \\
$\mathbf{M e a n}$ & $4.63^{\mathrm{a}}$ & $4.60^{\mathrm{b}}$ & $4.57^{\mathrm{c}}$ & $4.54^{\mathrm{d}}$ & $4.50^{\mathrm{e}}$ &
\end{tabular}

D $: 0.4-\mathrm{D}_{3}: 0.6-\mathrm{D}_{4}: 0.8(\mathrm{gm} / \mathrm{L})$

\subsection{Antioxidant activity}

DPPH is a stable nitrogen-centred free radical, the colour of which changes from violet to yellow upon reduction by either the process of hydrogen- or electrondonation. Substances which are able to perform this reaction considered as antioxidants and therefore radical scavengers. Plant tissues contain a range of components that may be broadly classed as antioxidants. In this part Tables (4 and 5) showed the antioxidant activity in yoghurt made by different concentrations of Ciand Dsolvent extract and compared with plain yoghurt. $\mathrm{Ci}$ yoghurt exhibited higher significant scavenging activity at a concentration of $0.8 \mathrm{gm}$ with $74.79 \%$ inhibition, followed by $\mathrm{D}$ yoghurt at the same concentration with $70 \%$ inhibition, plain yoghurt was found to have a lower scavenging effect, since it showed $52.08 \%$ inhibition. High potential of antioxidant activity of $\mathrm{Ci}$ bark and D seed solvent extract may be due to that they are rich in 
phytochemical contents, which possessed high antioxidant (Christova-Bagdassarian et al., 2013). Inhibition of DPPH oxidation by each yoghurt increased significantly to the values of $79.74,75.89$, and $63.86 \%$ for $\mathrm{Ci}, \mathrm{D}$ and plain yoghurt, respectively on the $4^{\text {th }}$ day of refrigerated storage followed by gradual significant reduction in the $8^{\text {th }}$ day of storage period. Dill extract is rich in flavonoids and tannins. The reduction in antioxidant activities during refrigerated storage of yoghurt may be attributed to increasing degradation of phenolic compounds with antioxidant activities and/or increasing milk protein polyphenol interaction (Amirdivani and Baba, 2011).

Table (4): Antioxidant activity (\%) of yoghurt supplemented with different concentrations of cinnamon extract.

\begin{tabular}{|c|c|c|c|c|c|c|}
\hline \multirow{2}{*}{ Storage period (Days) } & \multicolumn{5}{|c|}{ Treatments } & \multirow{2}{*}{ Mean } \\
\hline & $\mathbf{C}$ & $\mathbf{C} \mathbf{i}_{1}$ & $\mathbf{C} \mathbf{i}_{2}$ & $\mathbf{C i}_{3}$ & $\mathbf{C i}_{4}$ & \\
\hline Zero time & 52.08 & 66.66 & 69.58 & 72.29 & 74.79 & $67.08^{\mathrm{b}}$ \\
\hline 4 & 63.86 & 74.33 & 76.52 & 78.02 & 79.74 & $74.47^{\mathrm{a}}$ \\
\hline 8 & 47.06 & 51.26 & 58.63 & 66.22 & 66.85 & $58.00^{\mathrm{c}}$ \\
\hline 12 & 34.65 & 39.35 & 40.09 & 41.83 & 43.56 & $39.89^{d}$ \\
\hline Mean & $49.41^{\mathrm{e}}$ & $57.90^{\mathrm{d}}$ & $61.20^{\mathrm{c}}$ & $64.58^{\mathrm{b}}$ & $66.21^{\mathrm{a}}$ & \\
\hline
\end{tabular}

The different letters means significant

Table (5): Antioxidant activity (\%) of yoghurt supplemented with different concentrations of dill extract.

\begin{tabular}{lcccccc}
\hline \multirow{2}{*}{ Storage period (Days) } & \multicolumn{3}{c}{ Treatments } & \multicolumn{1}{c}{ Mean } \\
\cline { 2 - 7 } & $\mathbf{C}$ & $\mathbf{D}_{\mathbf{1}}$ & $\mathbf{D}_{\mathbf{1}}$ & $\mathbf{D}_{\mathbf{1}}$ & $\mathbf{D}_{\mathbf{1}}$ & \\
\hline Zero time & 52.08 & 58.12 & 64.16 & 66.87 & 70 & $62.24^{\mathrm{b}}$ \\
$\mathbf{4}$ & 63.86 & 67.03 & 69.90 & 73.64 & 75.89 & $70.06^{\mathrm{a}}$ \\
$\mathbf{8}$ & 47.06 & 53.39 & 57.19 & 60.93 & 63.29 & $56.37^{\mathrm{c}}$ \\
$\mathbf{1 2}$ & 34.65 & 35.64 & 38.36 & 40.34 & 41.08 & $38.01^{\mathrm{d}}$ \\
Mean & $49.41^{\mathrm{e}}$ & $53.54^{\mathrm{d}}$ & $57.40^{\mathrm{c}}$ & $60.44^{\mathrm{b}}$ & $62.56^{\mathrm{a}}$ &
\end{tabular}

The different letters means significant

\subsection{Total Phenolic Content (TPC)}

Phenolic compounds in plants constitute a major class of secondary plant metabolites with bioactive potential attributed to antioxidant activities. Tables (6 and 7) showed the amounts of total phenolic content in $\mathrm{Ci}$ and $\mathrm{D}$ solvent extract yoghurt and compared with control yoghurt. The TPC values of supplemented yoghurt with different concentrations of $\mathrm{Ci} \& \mathrm{D}$ ethanolic extract were higher than plain yoghurt and increased significantly with the increasing the extracts concentrations from 0.2 to $0.8 \mathrm{gm}$. Maximum TPC found at day 4 of storage period with values of $17.10,16.33$ and $10.94 \mathrm{mg}$ gallic acid/100gm of $\mathrm{Ci}, \mathrm{D}$, and plain yoghurt samples respectevily (Foda et al., 2007). the TPC values in plain-yoghurt reflect phenolic compounds whichrelated to milk protein breakdown. The amino acid tyrosin for instance has a phenolic side chain suggested to give rise to the reading of TPC. Another possibility is that microbial utilization of phenolic acids such as ferulic and p-coumaric acid during fermentation process and post acidification lead to the production of other phenolic acids such as vanillic and $\mathrm{p}$ hydroxybenzoic acids before the aromatic ring structure is broken down. The increased TPC in herbalyoghurts can be explained by the presence of indigenous phytochemical compounds in herbs during storage period (e.g., flavonoids and phenolic compounds) in A. graveolens (dill).As in antioxidant activity TPC content generally dropped at the 8th day of storage (Tseng and Zhao, 2012).

\subsection{Thiobarbaturic acid (TBA) values}

The secondary oxidation products such as malonaldehyde and 2-alkenals, are measured by thiobarbituric. The effects of solvent extracts of $\mathrm{Ci}$ bark and $\mathrm{D}$ seed on malonaldehyde formation of yoghurt samples stored at $4^{\circ} \mathrm{C}$ for 12 day in terms of incubation time versus TBA value are shown in Tables ( 8 and 9). The results of TBA values decreased with increasing the level of $\mathrm{Ci}$ extracts, at zero time $\mathrm{Ci}$ bark solvent extract showed significant high activity for preventing the 
formation of secondary oxidation products to be 0.0145 as TBA values, followed by $\mathrm{D}$ seed and plain yoghurt to be 0.0185 and 0.038 respectively. On the other hand, the malondehyde formation of all yoghurt samples increased significantly during storage time. At the end of the storage period the $\mathrm{Ci}$ and $\mathrm{D}$ extract treatments were appeared as being the most effective antioxidants in terms of inhibition of malonaldehyde formation. It could be concluded that the oxidation products were initially low and increased rapidly specially in the control samples during storage, however, a much slower rate of increase in oxidation products was observed in yoghurt samples treated with $\mathrm{Ci}$ and $\mathrm{D}$ solvent extracts. This is closely related to the presence of phenolic compounds as Cinnamaldehyde, Eugenol, Limonene, Carvone and Apiole which are the most abundant phenol compounds known in $\mathrm{Ci}$ and $\mathrm{D}$ extracts. So they are mainly responsible for free radical inhibitors, due to their ability to break the chain reaction during the propagation phase of oxidation by scavenging or reacting with free radicals to produce non-radical compounds, due to their high level of hydrogen donation (Rasmy et al., 2012).

\subsection{Aroma compound}

\subsubsection{Acetaldehyde and Diacetyle}

Data presented in Figs (1 and 2) showed the effect of solvent extract of $\mathrm{Ci}$ bark and $\mathrm{D}$ seed on the acetaldehyde values of yoghurt at different concentrations. Ci \& D extract yoghurt had significant higher values of acetaldehyde than plain yoghurt and high concentrations of acetaldehyde were necessary to produce a desirable flavor in yoghurt. The higher concentration of acetaldehyde was reported to be due to the low utilization rate of this compound. The lack of alcohol dehydrogenase enzyme in the bacteria, responsible for the conversion of acetaldehyde into ethanol, which was suggested to be the reason of low utilization of acetaldehyde. Good flavor resulted when concentration was greater than $8.0 \mathrm{ppm}$ of acetaldehyde was produced. The highest values obtained for yoghurt containing $0.8 \mathrm{mg}$ of $\mathrm{Ci}$ extract was $69.7 \mathrm{ppm}$ while the lowest values obtained for the untreated control yoghurt was $46.9 \mathrm{ppm}$. Concerning diacetyle, data presented in Figs (3 and 4) exhibit that its production approximately took the same trend of acedaldehyde production at cold storage period. The harsh flavors were caused by overproduction of acetaldehyde in comparison with to diacetyl. Despite the controversies over the role of diacetyl in the overall aroma expression of yogurt, diacetyl was one of the other major aroma compounds. Yoghurt supplemented with cinnamon extract contained the highest level of acetaldehyde and diacetyle whatever at zero time or during cold storage period followed by dill extract.

Table (6): Total phenolic content (TPC) (mg Gallic acid/100 gm sample) of yoghurt supplemented with different concentrations of cinnamon extract.

\begin{tabular}{lcccccc}
\hline \multirow{2}{*}{ Storage period (Days) } & \multicolumn{7}{c}{ Treatments } & & \multicolumn{1}{c}{ Mean } \\
\cline { 2 - 7 } & $\mathbf{C}$ & $\mathbf{C i}_{\mathbf{1}}$ & $\mathbf{C i}_{\mathbf{2}}$ & $\mathbf{C i}_{\mathbf{3}}$ & $\mathbf{C i}_{\mathbf{4}}$ & \\
\hline Zero time & 9.28 & 11.17 & 13.03 & 14.69 & 16.13 & $12.86^{\mathrm{b}}$ \\
$\mathbf{4}$ & 10.94 & 11.69 & 13.98 & 16.10 & 17.10 & $13.96^{\mathrm{a}}$ \\
$\mathbf{8}$ & 8.70 & 10.20 & 11.60 & 13.26 & 14.46 & $11.64^{\mathrm{c}}$ \\
$\mathbf{1 2}$ & 4.40 & 9.16 & 10.28 & 11.40 & 12.23 & $9.49^{\mathrm{d}}$ \\
Mean & $8.33^{\mathrm{e}}$ & $10.55^{\mathrm{d}}$ & $12.22^{\mathrm{c}}$ & $13.86^{\mathrm{b}}$ & $14.98^{\mathrm{a}}$ & \\
\hline
\end{tabular}

The different letters means significant

Table (7): Total phenolic content (TPC) (mg Gallic acid/100 gm sample) of yoghurt supplemented with different concentrations of dill extract.

\begin{tabular}{lcccccc}
\hline \multirow{2}{*}{ Storage period(Day) } & \multicolumn{3}{c}{ Treatments } & \multicolumn{1}{c}{ Mean } \\
\cline { 2 - 7 } & $\mathbf{C}$ & $\mathbf{D}_{\mathbf{1}}$ & $\mathbf{D}_{\mathbf{2}}$ & $\mathbf{D}_{\mathbf{3}}$ & $\mathbf{D}_{\mathbf{4}}$ & \\
\hline Zero time & 9.28 & 10.16 & 11.77 & 13.40 & 14.61 & $11.84^{\mathrm{b}}$ \\
$\mathbf{4}$ & 10.94 & 11.40 & 13.41 & 14.89 & 16.33 & $13.39^{\mathrm{a}}$ \\
$\mathbf{8}$ & 8.70 & 9.16 & 10.88 & 12.03 & 13.38 & $10.83^{\mathrm{c}}$ \\
$\mathbf{1 2}$ & 4.40 & 7.83 & 9.16 & 10.31 & 11.57 & $8.65^{\mathrm{d}}$ \\
Mean & $8.33^{\mathrm{e}}$ & $9.63^{\mathrm{d}}$ & $11.30^{\mathrm{c}}$ & $12.65^{\mathrm{b}}$ & $13.97^{\mathrm{a}}$ &
\end{tabular}


Table (8): TBA absorbance of yoghurt supplemented with different concentrations of cinnamon extract.

\begin{tabular}{lcccccc}
\hline \multirow{2}{*}{ Storage period (Days) } & \multicolumn{7}{c}{ Treatments } & & Mean \\
\cline { 2 - 7 } Zero time & $\mathbf{C}$ & $\mathbf{C i}_{\mathbf{1}}$ & $\mathbf{C i}_{\mathbf{2}}$ & $\mathbf{C i}_{\mathbf{3}}$ & $\mathbf{C i}_{\mathbf{4}}$ & $0.023^{\mathrm{d}}$ \\
$\mathbf{4}$ & 0.038 & 0.029 & 0.018 & 0.016 & 0.0145 & $0.029^{\mathrm{c}}$ \\
$\mathbf{8}$ & 0.0435 & 0.0345 & 0.0255 & 0.0235 & 0.0205 & $0.036^{\mathrm{b}}$ \\
$\mathbf{1 2}$ & 0.053 & 0.0425 & 0.032 & 0.0295 & 0.025 & $0.042^{\mathrm{a}}$ \\
Mean & 0.063 & 0.048 & 0.039 & 0.035 & 0.0315 & \\
\hline
\end{tabular}

The different letters means significant

Table (9): TBA absorbance of yoghurt supplemented with different concentrations of dill extract.

\begin{tabular}{|c|c|c|c|c|c|c|}
\hline \multirow{2}{*}{ Storage period (Days) } & \multicolumn{5}{|c|}{ Treatments } & \multirow{2}{*}{ Mean } \\
\hline & $\mathbf{C}$ & $\mathbf{D}_{1}$ & $\mathbf{D}_{2}$ & $\mathbf{D}_{3}$ & $\mathbf{D}_{4}$ & \\
\hline Zero time & 0.038 & 0.0305 & 0.024 & 0.019 & 0.0185 & $0.026^{\mathrm{d}}$ \\
\hline 4 & 0.0435 & 0.036 & 0.031 & 0.028 & 0.0235 & $0.032^{\mathrm{c}}$ \\
\hline 8 & 0.053 & 0.047 & 0.0365 & 0.034 & 0.0295 & $0.04^{\mathrm{b}}$ \\
\hline 12 & 0.063 & 0.0545 & 0.0445 & 0.0405 & 0.035 & $0.047^{\mathrm{a}}$ \\
\hline Mean & $0.049^{\mathrm{a}}$ & $0.042^{\mathrm{b}}$ & $0.034^{\mathrm{c}}$ & $0.030^{\mathrm{cd}}$ & $0.026^{\mathrm{d}}$ & \\
\hline
\end{tabular}

The different letters means significant.

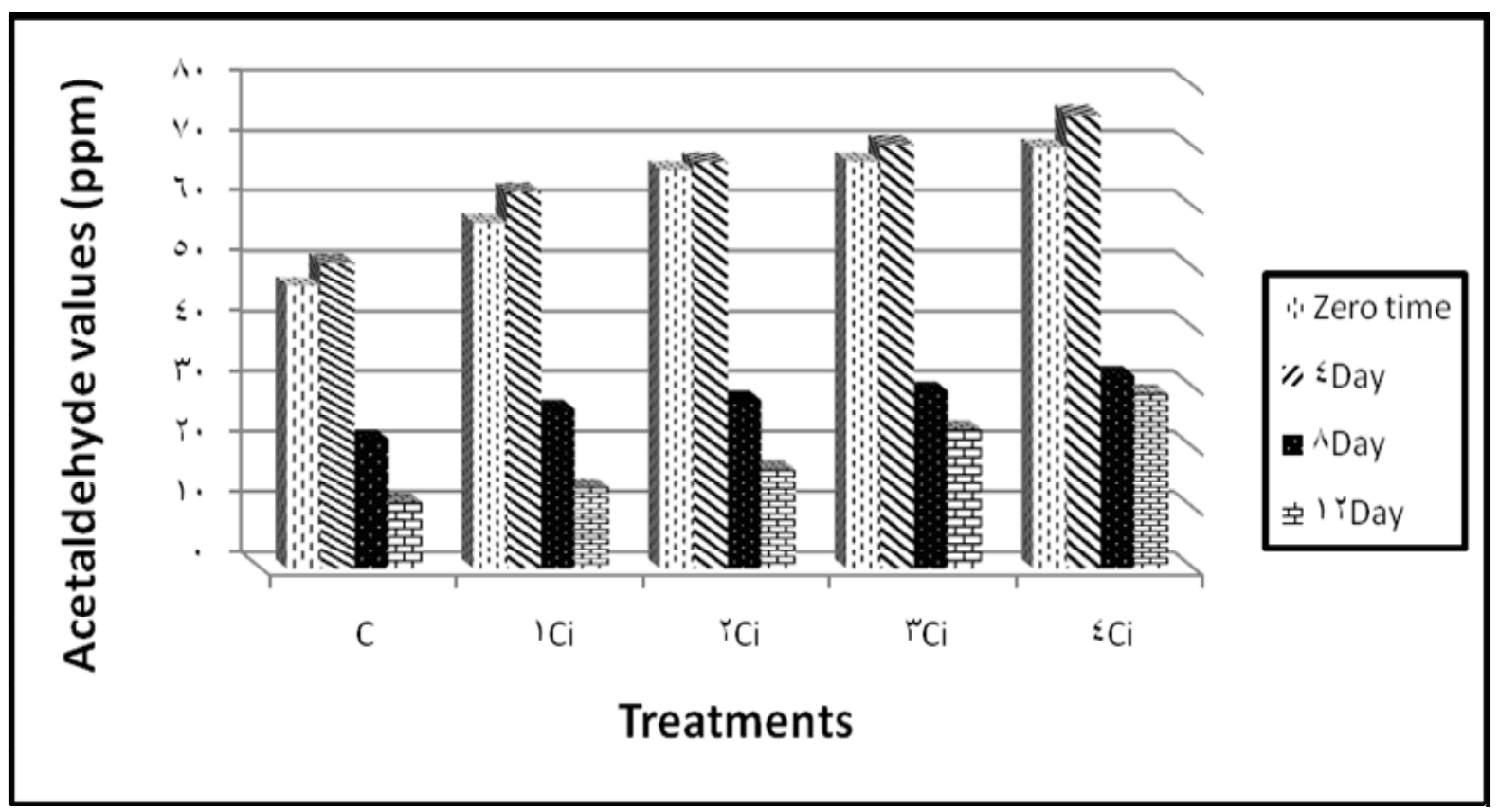

Fig (1): Acetaldehyde (ppm) of yoghurt supplemented with different concentrations of cinnamon extract. 


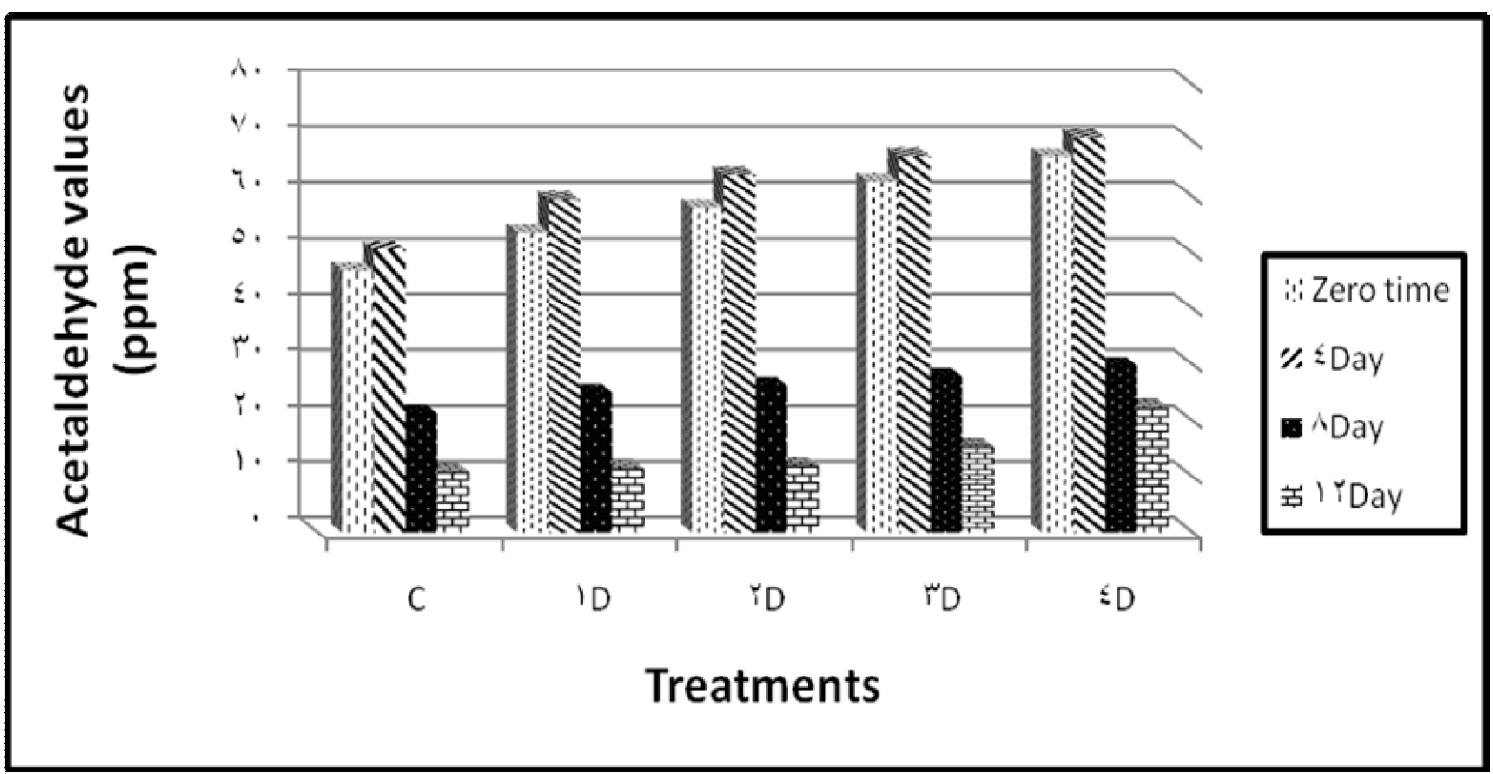

Fig (2): Acetaldehyde (ppm) of yoghurt supplemented with different concentrations of dill extract.

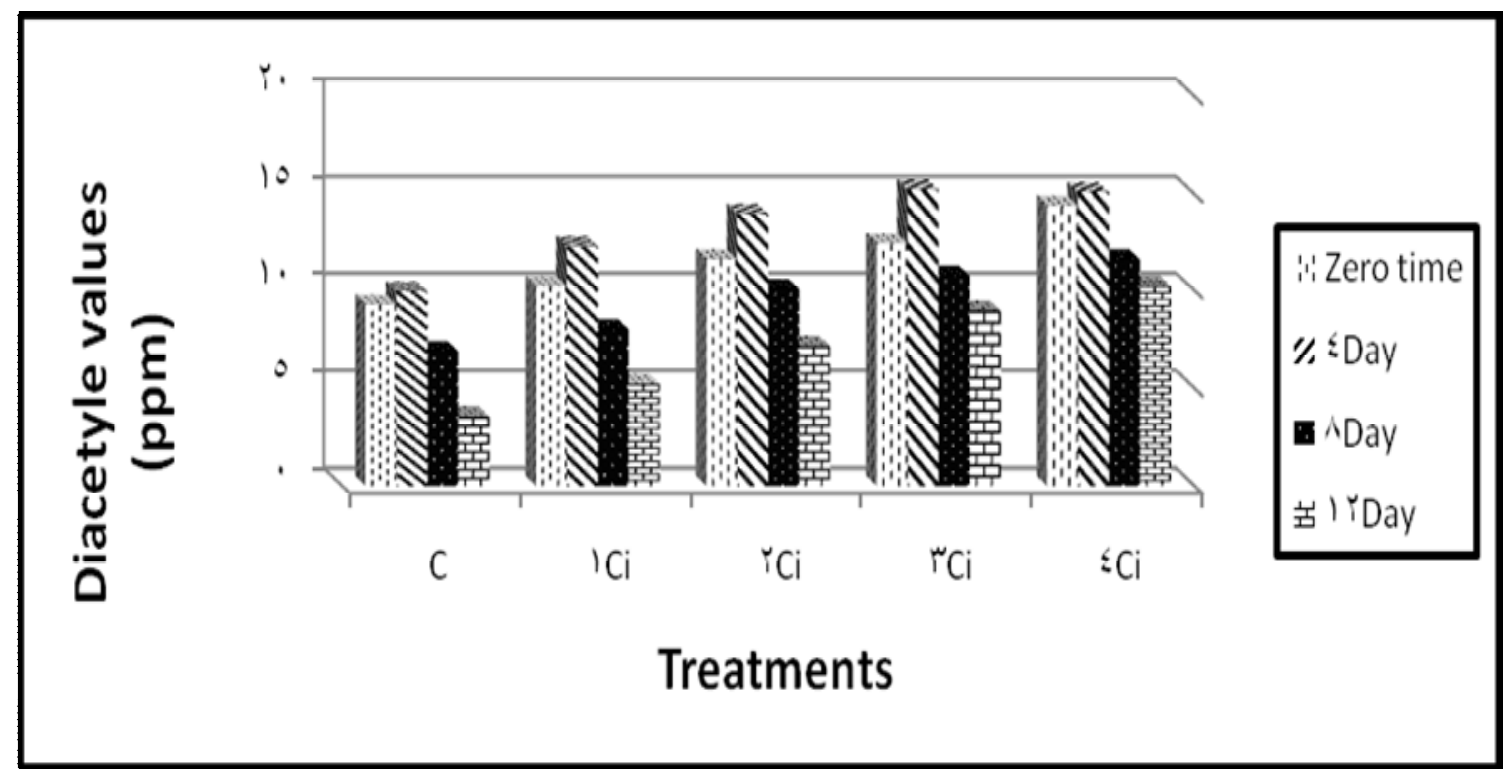

Fig (3): Diacetyle (ppm) of yoghurt supplemented with different concentrations of cinnamon extract.

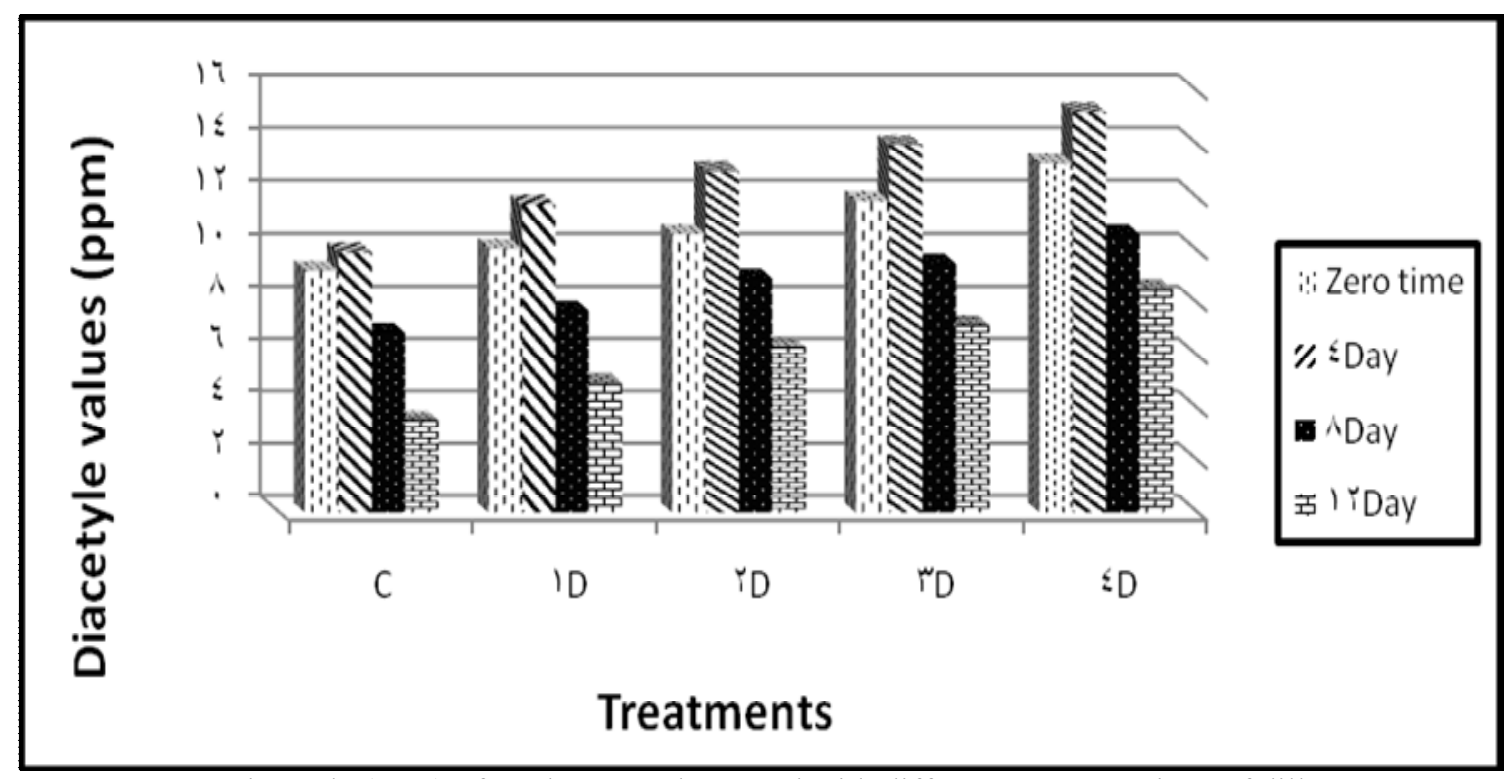

Fig (4): Diacetyle (ppm) of yoghurt supplemented with different concentrations of dill extract. 


\subsection{Rheological properties}

\subsubsection{Synersis (whey off)}

The syneresis of yoghurt was affected significantly by both extract concentration and storage time; the changes are shown in Tables (10 and 11).The results indicated that the addition of $\mathrm{Ci}$ bark and $\mathrm{D}$ seed extracts to the yoghurt at different concentrations decreased the level of whey loss of fresh yoghurt, from $8.5 \mathrm{~mL}$ of control to $6.75 \mathrm{~mL}$ and $4.9 \mathrm{~mL}$ non significantly for the $\mathrm{Ci}$ and $\mathrm{D}$ yoghurt, respectively. It is known that faster rates of acidification results in higher levels of whey separation however, these results demonstrated that although extracts induced high rates of acidification and earlier gelation of milk gels, the incorporation of $\mathrm{Ci}$ and $\mathrm{D}$ extracts into the yoghurt formulation also reduced the whey loss. Data showed that the value of whey off of D extract yoghurt was lower than in $\mathrm{Ci}$ extract yoghurt. The results from the rheological measurements and microstructure characterization suggest that $\mathrm{D}$ extract at the $\mathrm{pH}$ of yoghurt could interact with the protein matrix through electrostatic interactions and particles are soft deformable particles that can hold a large amount of water, With an increase in the concentration of $\mathrm{D}$ extract into the yoghurt formulation, its gel network would become denser with less void space within the network, thus resulting in an increase in the gel firmness and reduction in whey loss (McCann and Li Day, 2011). Generally in all treatments the values of whey off increased at the end of storage period this was referred to the decreased in the $\mathrm{pH}$ values, but the control yoghurt had significant highest values of the whey off at the end of storage period.

Table (10): Synersis ( $\mathrm{ml}$ whey/25 gm) of yoghurt supplemented with different concentrations of cinnamon extract.

\begin{tabular}{lccccccc}
\hline \multirow{2}{*}{ Storage period (Days) } & \multicolumn{5}{c}{ Treatments } & \multicolumn{1}{c}{ Mean } \\
\cline { 2 - 7 } & $\mathbf{C}$ & $\mathbf{C i}_{\mathbf{1}}$ & $\mathbf{C i}_{\mathbf{2}}$ & $\mathbf{C i}_{\mathbf{3}}$ & $\mathbf{C i}_{\mathbf{4}}$ & \\
\hline Zero time & 8.5 & 7.8 & 7.1 & 7 & 6.75 & $7.49^{\mathrm{a}}$ \\
$\mathbf{4}$ & 7.75 & 7.3 & 6.55 & 5.9 & 5.3 & $6.56^{\mathrm{b}}$ \\
$\mathbf{8}$ & 7.05 & 6.25 & 5.8 & 5.05 & 4.55 & $5.74^{\mathrm{c}}$ \\
$\mathbf{1 2}$ & 10.35 & 8 & 7 & 6.35 & 5.6 & $7.46^{\mathrm{a}}$ \\
Mean & $8.41^{\mathrm{a}}$ & $7.41^{\mathrm{b}}$ & $6.61^{\mathrm{bc}}$ & $6.07^{\mathrm{cd}}$ & $5.55^{\mathrm{d}}$ &
\end{tabular}

The different letters means significant

Table (11): Synersis ( $\mathrm{ml}$ whey/25 gm) of yoghurt supplemented with different concentrations of dill extract.

\begin{tabular}{lccccccc}
\hline \multirow{2}{*}{ Storage period (Days) } & \multicolumn{3}{c}{ Treatments } & \multicolumn{1}{c}{ Mean } \\
\cline { 2 - 7 } Zero time & $\mathbf{C}$ & $\mathbf{D}_{\mathbf{1}}$ & $\mathbf{D}_{\mathbf{2}}$ & $\mathbf{D}_{\mathbf{3}}$ & $\mathbf{D}_{\mathbf{4}}$ & \\
\hline $\mathbf{4}$ & 8.5 & 6.45 & 5.7 & 5.3 & 4.9 & $6.17^{\mathrm{a}}$ \\
$\mathbf{8}$ & 7.75 & 5.85 & 5.4 & 4.75 & 4.2 & $5.59^{\mathrm{ab}}$ \\
$\mathbf{1 2}$ & 7.05 & 5.3 & 4.8 & 4 & 3.6 & $4.95^{\mathrm{b}}$ \\
Mean & 10.35 & 7.05 & 6 & 5.4 & 4.75 & $6.71^{\mathrm{a}}$ \\
\hline
\end{tabular}

The different letters means significant

\subsubsection{Firmness values}

Yoghurt firmness as affected by different concentrations of $\mathrm{Ci}$ and $\mathrm{D}$ extracts in fresh or during cold storage at $4^{\circ} \mathrm{C}$ for 12 days are presented in Tables (12 and 13). Adding of $\mathrm{Ci}$ and $\mathrm{D}$ extracts was increased yoghurt firmness significantly compared with control samples. Moreover, firmness values increased as the $\mathrm{Ci}$ and $\mathrm{D}$ extracts increased to be $40,35.2,22.5$ for $\mathrm{D}, \mathrm{Ci}$, and plain yoghurt respectively when fresh. These results may be due to the rearrangement within the network produced by attractive forces between individual casein particles and these extracts leading to affect the yoghurt gel (foda et al., 2007). The firmness values of yoghurt manufacture with different concentrations of $\mathrm{D}$ extract was higher than of $\mathrm{Ci}$ extract yoghurt because of particles of dill extract are soft deformable particles that can hold a large amount of water.

\subsubsection{Apparent viscosity properties}

Data presented in Tables (14 and 15) showed the effect of different concentrations of $\mathrm{Ci}$ and $\mathrm{D}$ extracts on one of rheological parameter of yoghurt like apparent viscosity. dill extract yoghurt recorded higher values of apparent viscosity than $\mathrm{Ci}$ yoghurt to be 1522.5, 1516 and 923.6for $\mathrm{D}, \mathrm{Ci}$, and control yoghurt respectively, this reflected that $\mathrm{D}$ powder may be more interaction with milk protein (foda et al., 2007). In all samples apparent viscosity increased significantly as storage period increased. Finally yoghurt with high milk viscosity tends to have high Firmness (Barrantes et al., 1994). 
Table (12): Firmness values of yoghurt supplemented with different concentrations of cinnamon extract (used brabender units).

\begin{tabular}{lcccccc}
\hline \multirow{2}{*}{ Storage period (Days) } & $\mathbf{9}$ Treatments & \multirow{2}{*}{ Mean } \\
\cline { 2 - 6 } & $\mathbf{C}$ & $\mathbf{C i}_{\mathbf{1}}$ & $\mathbf{C i}_{\mathbf{2}}$ & $\mathbf{C i}_{\mathbf{3}}$ & $\mathbf{C i}_{\mathbf{4}}$ & \\
\hline Zero time & 22.5 & 26.5 & 28.5 & 32.75 & 35.2 & $29.09^{\mathrm{c}}$ \\
$\mathbf{4}$ & 24.5 & 31 & 35.5 & 37.5 & 38.5 & $33.4^{\mathrm{b}}$ \\
$\mathbf{8}$ & 30 & 35 & 37 & 39 & 39 & $36^{\mathrm{a}}$ \\
$\mathbf{1 2}$ & 20 & 24.5 & 28.5 & 33 & 34.5 & $28.1^{\mathrm{c}}$ \\
Mean & $24.25^{\mathrm{d}}$ & $29.25^{\mathrm{c}}$ & $32.37^{\mathrm{b}}$ & $35.56^{\mathrm{a}}$ & $36.8^{\mathrm{a}}$ & \\
\hline
\end{tabular}

The different letters means significant

Table (13): Firmness values of yoghurt supplemented with different concentrations of dill extract (used brabender units).

\begin{tabular}{lcccccc}
\hline \multirow{2}{*}{ Storage period (Days) } & \multicolumn{7}{c}{ Treatments } & \multirow{2}{*}{ Mean } \\
\cline { 2 - 6 } & $\mathbf{C}$ & $\mathbf{D}_{\mathbf{1}}$ & $\mathbf{D}_{\mathbf{2}}$ & $\mathbf{D}_{\mathbf{3}}$ & $\mathbf{D}_{\mathbf{4}}$ & \\
\hline Zero time & 22.5 & 30 & 32.5 & 37 & 40 & $32.4^{\mathrm{c}}$ \\
$\mathbf{4}$ & 24.5 & 35.5 & 36.75 & 40.5 & 44.7 & $36.39^{\mathrm{b}}$ \\
$\mathbf{8}$ & 30 & 37.5 & 39.75 & 43 & 46 & $39.25^{\mathrm{a}}$ \\
$\mathbf{1 2}$ & 20 & 28 & 31 & 37 & 38.75 & $30.95^{\mathrm{c}}$ \\
Mean & $24.25^{\mathrm{e}}$ & $32.75^{\mathrm{d}}$ & $35^{\mathrm{c}}$ & $39.37^{\mathrm{b}}$ & $42.36^{\mathrm{a}}$ & \\
\hline
\end{tabular}

The different letters means significant

Table (14): Apparent viscosity (mpas) properties of yoghurt supplemented with different concentrations of cinnamon extract.

\begin{tabular}{lcccccc}
\hline \multirow{2}{*}{ Storage period (Days) } & \multicolumn{5}{c}{ Treatments } & \multirow{2}{*}{ Mean } \\
\cline { 2 - 6 } & $\mathbf{C}$ & $\mathbf{C i}_{\mathbf{1}}$ & $\mathbf{C i}_{\mathbf{2}}$ & $\mathbf{C i}_{\mathbf{3}}$ & $\mathbf{C i}_{\mathbf{4}}$ & \\
\hline Zero time & 923.6 & 1055.5 & 1291.5 & 1462 & 1516 & $1249.72^{\mathrm{d}}$ \\
$\mathbf{4}$ & 1048.5 & 1222.5 & 1457 & 1540 & 1640 & $1381.6^{\mathrm{c}}$ \\
$\mathbf{8}$ & 1166.5 & 1491.5 & 1569.5 & 1730.5 & 1928 & $1577.2^{\mathrm{b}}$ \\
$\mathbf{1 2}$ & 1327 & 1590.5 & 1749 & 1951 & 2243 & $1772.1^{\mathrm{a}}$ \\
$\mathbf{M e a n}$ & $1116.4^{\mathrm{e}}$ & $1340^{\mathrm{d}}$ & $1516.75^{\mathrm{c}}$ & $1670.8^{\mathrm{b}}$ & $1831.7^{\mathrm{a}}$ & \\
\hline
\end{tabular}

The different letters means significant

Table (15): Apparent viscosity (mpas) properties of yoghurt supplemented with different concentrations of dill extract.

\begin{tabular}{lcccccc}
\hline \multirow{2}{*}{ Storage period (Days) } & \multicolumn{7}{c}{ Treatments } & Mean \\
\cline { 2 - 7 } & $\mathbf{C}$ & $\mathbf{D}_{\mathbf{1}}$ & $\mathbf{D}_{\mathbf{2}}$ & $\mathbf{D}_{\mathbf{3}}$ & $\mathbf{D}_{\mathbf{4}}$ & \\
\hline Zero time & 923.6 & 1147 & 1326.5 & 1461.5 & 1522.5 & $1276.2^{\mathrm{d}}$ \\
$\mathbf{4}$ & 1048.5 & 1305.5 & 1500 & 1750 & 1793 & $1479.4^{\mathrm{c}}$ \\
$\mathbf{8}$ & 1166.5 & 1524 & 1708.5 & 1777.5 & 2018.5 & $1639^{\mathrm{b}}$ \\
$\mathbf{1 2}$ & 1327 & 1619.5 & 1827 & 1911.5 & 2409.5 & $1818.9^{\mathrm{a}}$ \\
Mean & $1116.4^{\mathrm{e}}$ & $1399^{\mathrm{d}}$ & $1590.5^{\mathrm{c}}$ & $1725.1^{\mathrm{b}}$ & $1935.8^{\mathrm{a}}$ &
\end{tabular}




\subsection{Organoleptic properties}

Tables (16 and 17) response of consumers to the idea of supplementing yoghurt with different concentrations of $\mathrm{Ci}$ and $\mathrm{D}$ extract. Flavor liking and total acceptance liking among the $0.2,0.4$ and $0.8 \mathrm{mg} \mathrm{Ci}$ solvent extract yoghurt similar to control yoghurt by the panelists. However, $0.8 \mathrm{Ci}$ extract yoghurt sample received significant lower score on flavor and total acceptance. Regarding the flavor evaluation of yoghurt supplemented with different concentrations of dill extract, Some panelists indicated their appreciation for taste of D extract yoghurt, but others stated their disliking related to aftertaste which might come from the astringency of tannin D extract, so that yoghurt was accepted significantly with 0.2 and $0.4 \mathrm{mg}$ of D extract up to the $12^{\text {th }}$ day of storage period. So it was obvious that lower concentration of D extract $(0.2 \& 0.4)$ has got the highest preference score. However increasing D extract concentration reduced the acceptability of yoghurt similar observations were reported by (foda et al., 2007). Appearance and color of $\mathrm{Ci}$ extract yoghurt decreased with increasing $\mathrm{Ci}$ concentrations compared to control yoghurt. D yoghurt had high score for appearance and color than in $\mathrm{Ci}$ yoghurt. From the foregoing results we could concluded that added cinnamon extract up to $0.6(\mathrm{~g} / \mathrm{L})$ and dill extract up to $0.4(\mathrm{~g} / \mathrm{L})$ to yoghurt milk improve the overall quality of the resultant yoghurt.

Table (16): The organoleptic properties of yoghurt supplemented with different concentrations of cinnamon extract.

\begin{tabular}{|c|c|c|c|c|c|}
\hline \multirow{2}{*}{ Treatments } & \multicolumn{4}{|c|}{ Storage period (days) } & \multirow{2}{*}{ Mean } \\
\hline & Zero time & 4 & 8 & 12 & \\
\hline \multicolumn{6}{|c|}{ Flavor (0-10) } \\
\hline Control & 9 & 9.25 & 9 & 8.75 & $9^{\mathrm{b}}$ \\
\hline $\mathbf{T} \mathbf{1}_{\mathrm{Ci}}$ & 9.5 & 9.5 & 9.5 & 9 & $9.37^{\mathrm{a}}$ \\
\hline $\mathbf{T} 2_{\mathrm{Ci}}$ & 9.5 & 9.5 & 9.5 & 9 & $9.37^{\mathrm{a}}$ \\
\hline $\mathbf{T} \mathbf{3}_{\mathrm{Ci}}$ & 9.25 & 9.25 & 8.75 & 8.25 & $8.87^{\mathrm{b}}$ \\
\hline $\mathbf{T} 4_{\mathrm{Ci}}$ & 8.25 & 8.5 & 7.5 & 7.5 & $7.93^{\mathrm{c}}$ \\
\hline Mean & $9.1^{\mathrm{a}}$ & $9.2^{\mathrm{a}}$ & $8.85^{\mathrm{b}}$ & $8.5^{\mathrm{c}}$ & \\
\hline \multicolumn{6}{|c|}{ (Body \& Texture 0-5) } \\
\hline Control & 4.25 & 4.25 & 4.25 & 3.75 & $4.12^{\mathrm{a}}$ \\
\hline $\mathbf{T} 1_{\mathrm{Ci}}$ & 4 & 4 & 4 & 3.75 & $3.93^{\mathrm{b}}$ \\
\hline $\mathbf{T} 2_{\mathrm{Ci}}$ & 4 & 4 & 4 & 3.75 & $3.93^{\mathrm{b}}$ \\
\hline $\mathbf{T} \mathbf{3}_{\mathrm{Ci}}$ & 4 & 4 & 4 & 3.25 & $3.81^{\mathrm{b}}$ \\
\hline $\mathbf{T} 4_{\mathrm{Ci}}$ & 4 & 4 & 4 & 3.25 & $3.81^{\mathrm{b}}$ \\
\hline Mean & $4.05^{\mathrm{a}}$ & $4.05^{\mathrm{a}}$ & $4.05^{\mathrm{a}}$ & $3.55^{\mathrm{b}}$ & \\
\hline \multicolumn{6}{|c|}{ Appearance and color (0-5) } \\
\hline Control & 4 & 4 & 4 & 4 & $4^{\mathrm{a}}$ \\
\hline $\mathbf{T} 1_{\mathrm{Ci}}$ & 3.75 & 3.75 & 3.75 & 3.75 & $3.75^{\mathrm{b}}$ \\
\hline $\mathbf{T} 2_{\mathrm{Ci}}$ & 3.75 & 3.75 & 3.75 & 3.75 & $3.75^{\mathrm{b}}$ \\
\hline $\mathbf{T} 3_{\mathrm{Ci}}$ & 3.75 & 3.75 & 3.75 & 3.75 & $3.75^{\mathrm{b}}$ \\
\hline $\mathbf{T} 4_{\mathrm{Ci}}$ & 3.75 & 3.75 & 3.75 & 3.75 & $3.75^{\mathrm{b}}$ \\
\hline Mean & $3.8^{\mathrm{a}}$ & $3.8^{\mathrm{a}}$ & $3.8^{\mathrm{a}}$ & $3.8^{\mathrm{a}}$ & \\
\hline \multicolumn{6}{|c|}{ Total acceptance $(0-20)$} \\
\hline Control & 17.25 & 17.5 & 17.25 & 16.5 & $17.12^{\mathrm{a}}$ \\
\hline $\mathbf{T} \mathbf{1}_{\mathrm{Ci}}$ & 17.75 & 17.75 & 17.75 & 16.75 & $17.06^{\mathrm{a}}$ \\
\hline $\mathbf{T} 2_{\mathrm{Ci}}$ & 17.75 & 17.75 & 17.75 & 16.75 & $17.06^{\mathrm{a}}$ \\
\hline $\mathbf{T} \mathbf{3}_{\mathrm{Ci}}$ & 17.5 & 17.5 & 16.75 & 16 & $16.43^{b}$ \\
\hline $\mathbf{T} 4_{\mathrm{Ci}}$ & 16.5 & 16.75 & 15.5 & 15.25 & $15.5^{\mathrm{c}}$ \\
\hline Mean & $16.95^{\mathrm{ab}}$ & $17.05^{\mathrm{a}}$ & $16.7^{\mathrm{b}}$ & $15.85^{\mathrm{c}}$ & \\
\hline
\end{tabular}

The different letters means significant 
Table (17): The organoleptic properties of yoghurt supplemented with different concentrations of dill extract.

\begin{tabular}{|c|c|c|c|c|c|}
\hline \multirow{2}{*}{ Treatments } & \multicolumn{4}{|c|}{ Storage period (days) } & \multirow{2}{*}{ Mean } \\
\hline & Zero time & 4 & 8 & 12 & \\
\hline \multicolumn{6}{|c|}{ Flavor (0-10) } \\
\hline Control & 9 & 9.25 & 9 & 8.75 & $9^{a}$ \\
\hline $\mathbf{T} \mathbf{1}_{\mathbf{D}}$ & 9 & 8.75 & 8.5 & 7.5 & $8.43^{b}$ \\
\hline T2 D & 8.5 & 8.25 & 7.5 & 6.75 & $7.75^{\mathrm{c}}$ \\
\hline T3 & 7.75 & 7 & 6.75 & 6 & $6.87^{\mathrm{d}}$ \\
\hline T4 $4_{D}$ & 7 & 6 & 6.5 & 5.5 & $6.27^{\mathrm{e}}$ \\
\hline Mean & $8.25^{\mathrm{a}}$ & $7.85^{\mathrm{b}}$ & $7.66^{\mathrm{b}}$ & $6.9^{\mathrm{c}}$ & \\
\hline \multicolumn{6}{|c|}{ (Body \& Texture 0-5) } \\
\hline Control & 4.25 & 4.25 & 4.25 & 3.75 & $4.125^{b}$ \\
\hline $\mathbf{T} \mathbf{1}_{\mathbf{D}}$ & 4.5 & 4.5 & 4.5 & 4 & $4.37^{\mathrm{a}}$ \\
\hline T2 D & 4.5 & 4.5 & 4.5 & 4 & $4.37^{\mathrm{a}}$ \\
\hline T3 & 4.5 & 4.5 & 4.25 & 4 & $4.31^{\mathrm{a}}$ \\
\hline $\mathbf{T} 4_{D}$ & 4.5 & 4.5 & 4.25 & 4 & $4.31^{\mathrm{a}}$ \\
\hline Mean & $4.45^{\mathrm{a}}$ & $4.45^{\mathrm{a}}$ & $4.35^{\mathrm{a}}$ & $3.95^{\mathrm{b}}$ & \\
\hline \multicolumn{6}{|c|}{ Appearance and color (0-5) } \\
\hline Control & 4 & 4 & 4 & 4 & -- \\
\hline $\mathbf{T} \mathbf{1}_{\mathrm{D}}$ & 4 & 4 & 4 & 4 & -- \\
\hline$T 2_{D}$ & 4 & 4 & 4 & 4 & -- \\
\hline T3 $3_{D}$ & 4 & 4 & 4 & 4 & -- \\
\hline$T 4_{D}$ & 4 & 4 & 4 & 4 & -- \\
\hline \multicolumn{6}{|c|}{ Total acceptance $(0-20)$} \\
\hline Control & 17.25 & 17.5 & 17.25 & 16.5 & $17.12^{\mathrm{a}}$ \\
\hline$T 1_{D}$ & 17 & 16.75 & 16.5 & 15.25 & $16.81^{b}$ \\
\hline T2 D & 16.5 & 16.25 & 15.5 & 14.5 & $16.12^{\mathrm{c}}$ \\
\hline T3 & 15.75 & 15 & 14.75 & 13.25 & $15.18^{\mathrm{d}}$ \\
\hline T4 & 15 & 14 & 14.5 & 12.75 & $14.56^{\mathrm{e}}$ \\
\hline Mean & $16.7^{\mathrm{a}}$ & $16.3^{b}$ & $16^{\mathrm{c}}$ & $14.85^{\mathrm{d}}$ & \\
\hline
\end{tabular}

The different letters means significant

\section{REFERENCES}

Abou El-Nour, A. M., A.M. El-Kholy and M. H. Abd El-Salam (2004). Rheological properties of cow's milk yoghurt treated by transglutaminase (TGase). Egyptian J. Dairy Sci., 32 (1) 32: 37.

Amirdivani, S. and A. S. Baba (2011). Changes in yogurt fermentation characteristics, and antioxidant potential and in vitro inhibition of angiotensin-1 converting enzyme upon the inclusion of peppermint, dill and basil. Food Science and Technology, 44: 1458- 1464.

AOAC (1995). Association of official analysis chemists' official methods $15^{\text {th }}$ Ed. AOAC, Benjamin Franklin station, Washington, D.C. USA.

Barrantes, E., A.Y. Tamime and A.W. Sword (1994). Production of low-calorie yoghurt using skim milk powder and substitute 4-rheological properties. Milchwissenschaf, 49: 263-266.

Christova-Bagdassarian, V. L., K. S. Bagdassarian and M. S. Atanassova (2013). Phenolic profile, antioxidant and antimicrobial activities from the Apiaceae Family (Dry Seed). Mintage journal of Pharmaceutical \& Medical Sciences, 2(4): 27-31.

Costat (1998). Users manual for Costat version 6.311. Cohort software; Berkeley; CA.

Foda, M. I., M. Abd El-Aziz and A. A. Awad (2007). Chemical, rheological and sensory evaluation of yoghurt supplemented with turmeric. International Journal of Dairy Science, 2(3): 252259.

Goni, P., P. Lopez, C. Sanchez, R. Gomez-Lus, R. Becerril and C. Nerin (2009). Antimicrobial 
activity in the vapour phase of a combination of cinnamon and clove essential oils. Food Chemistry, 116: 982-989.

Gonzalez, N. J., K. Adhikari and M. F. Sancho-Madriz (2011). Sensory characteristics of peach-flavored yogurt drinks containing prebiotics and synbiotics. Food Science and Technology, 44: 158-163.

Lee, G. J. and G. R. jago (1969). Methods for the estimation of acetaldehyde in cultured dairy products, the Australian journal of Dairy Technology, 24: 181-190.

Li, W., F.S. Hosseinian, A. Tsopmo, J.K. Friel and T. Beta (2009). Evaluation of antioxidant capacity and aroma quality of breast milk. Nutrition, 25: 105-114.

McCann, T. H. and F. F. Li Day (2011). Microstructure, rheology and storage stability of low-fat yoghurt structured by carrot cell wall particles. Food Research International, 44:884-892.

Pearson, (1976). The chemical analysis of foods. $7^{\text {th }}$ ed., Churchill Livingstone. Edinburgh London and New York, pp. 525.

Rasmy, N. M., A. A. Hassan, M. I. Foda and M. M. ElMoghazy (2012). Assessment of the antioxidant activity of Sage (Salvia officinalis L.) extracts on the shelf life of Mayonnaise. World Journal of Dairy \& Food Sciences, 7(1): 28-40.

Rathore, S. S., S.N. Saxena, R. Saxena and R. Tilak (2013). Analysis of medicinally important compounds andanti-oxidant activity in fixed and essential oil of dill (Anethum graveolens L.) genotypes. International J. Seed Spices, 3(1): 1215.

Ravichandran, K., N.M.M.T. Saw, A.A.A. Mohdaly, A.M.M. Gabr, A. Kastell, H. Riedel, Z. Cai, D. Knorr and I. Smetanska (2013). Impact of processing of red beet on betalain content and antioxidant activity. Food Research International, 50: 670-675.

Senhaji, O., M. Faid and I. Kalalou (2007). Inactivation of Escherichia coli $\mathrm{O} 157: \mathrm{H7}$ by essential oil from Cinnamomum zeylanicum. The Brazilian Journal of Infectious Diseases, 11(2):234-236.

Smet, K., K. Raes, J. De Block, L. Herman, K. Dewettinck and K. Coudijzer (2008). A change in antioxidative capacity as a measure of onset to oxidation in pasteurized milk. International Dairy Journal, 18: 520-530.

Tamime, A. Y. and R. K. Robinson (1999). Yoghurt. Science and Technology. $2^{\text {nd }}$ Ed. Woodhead Publishing Ltd. Cambridge, London, UK.

Tseng, A. and Y. Zhao (2012). Wine grape pomace as antioxidant dietary fiber for enhancing nutritional value and improving storability of yogurt and salad dressing. Food Chemistry, 09: $1-40$.

Vahedi, N., M.M. Tehrani and F. Shahidi (2008). Optimizing of fruit yoghurt formulation and evaluating its quality during storage. AmericanEurasian J. Agric. \& Environ. Sci., 3(6):922-927.

\section{تأثثر إضافة تركيزات مختلفة للمستخلص الإيثانولي للقرفة وبذور الثبت على القيمة الصحية وخصائص

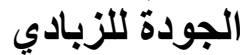

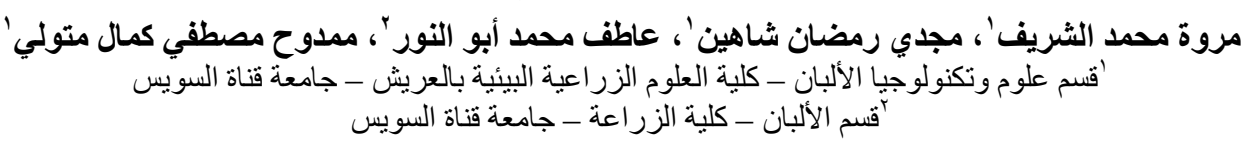

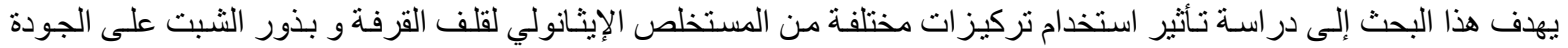

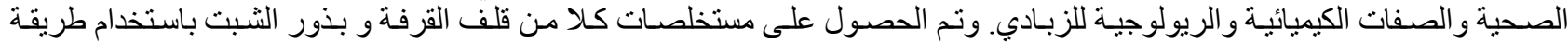

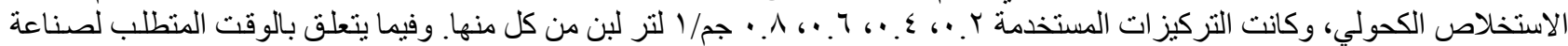

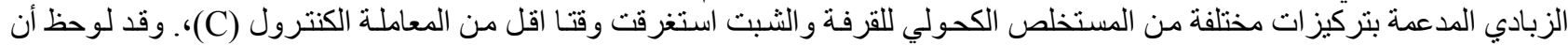

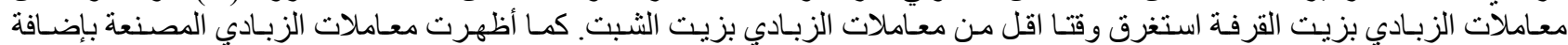

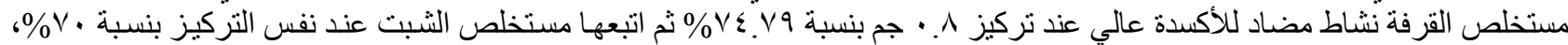

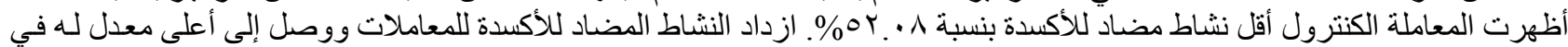

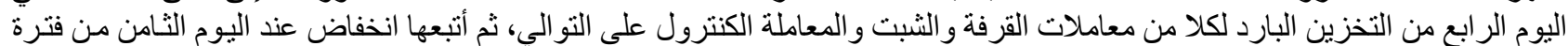

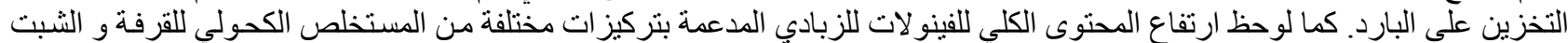

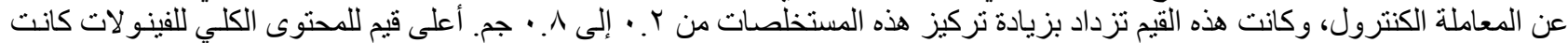

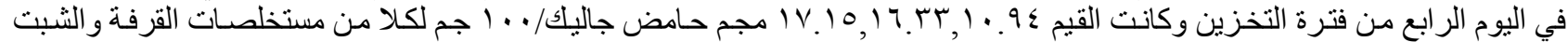

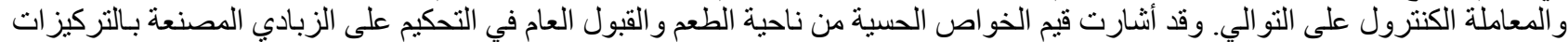

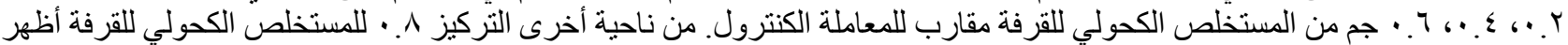

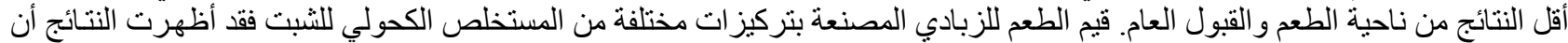

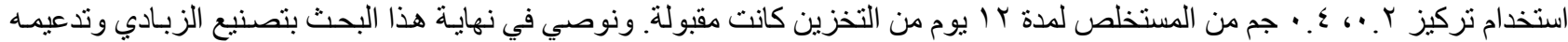

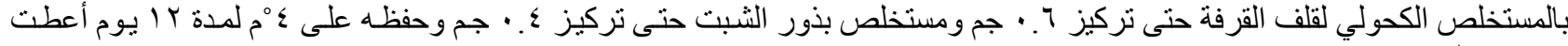

